\title{
History in
}

Africa

\section{A JOURNAL OF METHOD}



Published Annually by the AFRICAN STUDIES ASSOCIATION Vol. 33 / 2006 


\title{
HISTORY IN AFRICA
}

\author{
EDITORIAL BOARD
}

\author{
D.C. Conrad (SUNY/Oswego) \\ P.D. Curtin (Johns Hopkins University) \\ Adam Jones (Universität Leipzig) \\ R.C.C. Law (University of Stirling) \\ T.C. McCaskie (University of Birmingham) \\ J.C. Miller (University of Virginia) \\ A.D. Roberts (University of London) \\ M. Twaddle (University of London) \\ J. Vansina (University of Wisconsin/Madison) \\ Production Assistant \\ Jeff Kaufmann
}

History in Africa is published annually by the African Studies Association. Permission to reproduce materials from History in Africa should be obtained from the African Studies Association. Subscriptions and other business correspondence should be sent to the African Studies Association, Rutgers University, Douglass Campus, 132 George St., New Brunswick, NJ 08901-1400, U.S.A. (www.africanstudies.org) Manuscripts and other editorial correspondence should be sent to David Henige, Memorial Library, University of Wisconsin, Madison, WI 53706, U.S.A. Telephone: (608) 262-6397; Fax: (608) 265-2754, e-mail: dhenige@library.wisc.edu

Articles in History in Africa represent neither the views of the African Studies Association nor those of its officers. The editor is responsible for the final selection of the content of History in Africa and reserves the right to reject any material deemed inappropriate for publication. Responsibility for opinions expressed and for the accuracy of facts published rests solely with the individual authors. 


\title{
History in
} Africa

\section{A JOURNAL OF METHOD}

\author{
David Henige, Editor
}

\author{
Vol. 33 / 2006
}

\section{AFRICAN STUDIES ASSOCIATION}

Rutgers, The State University of New Jersey

Douglass Campus

132 George Street

New Brunswick, NJ 08901-1400 


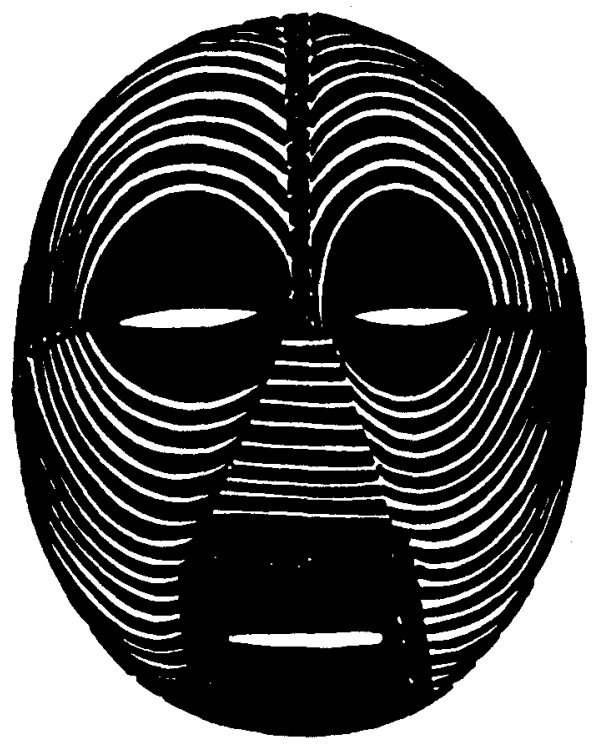

Luba painted wooden and china-clay mask, Zaire.

ISSN 0361-5413

(C) Copyright 2006

African Studies Association

All rights reserved.

No part of this publication may be reproduced or transmitted in any form or by any means, including photocopy, recording, or any information storage and retrieval system, without permission in writing from the publisher. Any author has a right to republish his article in whole or in part without requesting permission from the Association; others desiring permission to republish material should write to the African Studies Association. 


\section{HISTORY IN AFRICA}

\section{A Journal of Method}

\section{$33 / 2006$}

EDITOR

David Henige

University of Wisconsin-Madison

EDITORIAL BOARD

D.C. Conrad J.C. Miller

P.D. Curtin A.D. Roberts

Adam Jones M. Twaddle

R.C.C. Law J. Vansina

T.C. McCaskie

PRODUCTION ASSISTANT

Jeff Kaufmann

EDITORIAL OFFICE

David Henige

Memorial Library

University of Wisconsin

Madison, WI 53706 USA

tel 608.262 .6397

fax 608.265.2754

dhenige@library.wisc.edu

PUBLISHER

African Studies Association www.africanstudies.org

History in Africa 33(2006)

\section{CONTENTS}

Reconstructing Haberland

Reconstructing the

Wolaitta: Writing the

History and Society of a

Former Ethiopian Kingdom Jon Abbink

Teaching History in

Twentieth Century

Nigeria: the Challenges

of Change

Olutayo C. Adesina

The Spell of Oral History: a Case Study from Northern Igboland

A.E. Afigbo

The Contemporary

Significance of What Has

Been. Three Approaches

to Remembering the Past:

Lineage, Gada, and Oral

Tradition

Hermann Amborn

The History of

Africanization and the

Africanization of History

Esperanza

Brizuela-García 
Cabo Verde: Gulag of the South Atlantic: Racism, Fishing Prohibitions, and Famines

George E. Brooks

Anthropological Historical Research in Africa: How Do We Ask?

Tomas Sundnes Drønen

The Works of A.E. Afigbo on Nigeria: an

Historiographical Essay

Toyin Falola and Matthew Heaton

Precolonial Sub-Saharan

Africa and the Ancient Norse World: Looking for Similarities

Finn Fuglestad

Global Explanations

versus Local

Interpretations: the Historiography of the Influenza Pandemic of 1918-19 in Africa Matthew Heaton and Toyin Falola

Voices from Within and Without: Sources, Methods, and Problematics in the
Recovery of the Agrarian History of the Igbo (Southeastern Nigeria) Chima J. Korieh

History with a Mission: Abraham Kawadza and Narratives of Agrarian Change in Zimbabwe Todd H. Leedy

The Journey of Major. Rayne on the Banks of Turkwell River: Silent Political Assignment and Travel Writing Mustafa Kemal Mirzeler 271

Denying History in Colonial Kenya: the Anthropology and Archeology of G.W.B. Huntingford and L.S.B. Leakey J.E.G. Sutton

Linguistic Evidence for the Introduction of Ironworking into BantuSpeaking Africa Jan Vansina

Political Songs, Collective Memories, and Kikuyu Indi Schools

James A. Wilson, Jr. 
Acknowledging

Knowledge: Dissemination and Reception of Expertise in Colonial Africa

Dmitri van den Bersselaar

Cued Speeches: the Emergence of Shauri as Colonial Praxis in German East Africa, 1850-1903 Michael Pesek

Missionary Expertise, Social Science, and the Uses of Ethnographic Knowledge in Colonial Gabon Jobn M. Cinnamon

Missionary Knowledge and the State in Colonial Nigeria: On How G. T. Basden Became an Expert Dmitri van den Bersselaar

If You Can't Beat Them, Join Them: Government Cleansings of Witches and Mau Mau in 1950s Kenya

Katherine Luongo
Producing a Received View of Gold Coast Elite Society? C.F. Hutchison's Pen Pictures of Modern Africans and African Celebrities

Michel R. Doortmont

The German Maps at the East Africana Collection, University Library of Dar Es Salaam

Karin Pallaver

How to Distil Words and Obtain Culture History

$$
\text { Jan Vansina }
$$

Supplementary Notes on Charles John Andersson's Journey to the Okavango River

Edwin N. Wilmsen 